\title{
Knowledge and Attitudes of Pregnant Women regarding Painless Labour
}

\author{
Asmaa Nabwy Helmi Abo El-nassr ${ }^{1}$, Samia Abd-Elhakeem Hasneen Aboud ${ }^{2}$, Eman Mohamed \\ Abd El-hakam ${ }^{3}$ and Ola Abdel-wahab Afifi Araby ${ }^{4}$
}

(1) Nursing Specialist at Shebin Alkom Fever Hospital, Egypt, (2) Professor of Obstetrics and Gynecological Health Nursing, Faculty of Nursing, Benha University, Egypt, (3) Assistant Professor of Obstetrics and Gynecological Health Nursing, Faculty of Nursing, Benha University, Egypt and (4) Lecturer of Obstetrics and Gynecological Health Nursing, Faculty of Nursing, Benha University, Egypt

\begin{abstract}
Background: Painless labor refers to relieving labor pain via different methods of pain relief whether was pharmacological or non-pharmacological methods of pain relief. Aim of the study: Was to assess knowledge and attitudes of pregnant women regarding painless labor. Study design: A descriptive study was utilized. Setting: This study was conducted at Obstetrics \&Gynecology department at Benha University Hospital (Outpatient Clinic). Sampling: A purposive sample of 150 women who fulfill the inclusion criteria. Tools of data collection: Two tools were used for data collection; Tool I An interviewing-administered questionnaire sheet including two parts; (sociodemographic data and maternal knowledge assessment questionnaire regarding painless labor), tool II Modified Likert's scale to assess attitude of pregnant women regarding painless labor. Results: More than half of the studied women had poor knowledge and negative attitude regarding painless labor. Conclusion: There was a highly statistically significant positive correlation between total knowledge and attitude scores regarding painless labor Recommendations: Designing and applying educational classes for the health care provider and women about painless labor at different antenatal clinics.
\end{abstract}

Key words: Attitude, Knowledge, Labor, Pain Relief.

\section{Introduction}

Labor is a series of events that takes place in the genital organs in an effort to expel the viable products of conception (fetus, placenta and the membranes) out of the uterus through the vagina into the external environment. Labor is normal when labor occurs spontaneous in onset and at term, with vertex presentation, without undue prolongation, natural termination with minimal aids and without having any complications affecting the health of the mother and or the baby (Ackley, et al., 2021).

Labor pain is the result of many complex physiological and psychological interactions, both excitatory and inhibitory. The first stage of labor is associated with diffuse pain which originates from the dilatation and stretching of lower uterine segment and the cervix. Greater dilatation of the vagina and pressure on the perineum is responsible for the more intense somatic pain during the second stage of labor (Farnham, 2020).

A scientific definition of pain is 'an unpleasant sensory and emotional experience associated with actual or potential tissue damage'. Labor pain has its two elements: visceral and somatic. The visceral one occurs 
during the first stage of labor and it is exerted on the cervix, which causes its dilatation. That is felt by a parturient as a pain. The somatic kind of pain appears at the end of the first stage and it lasts also in the second stage. Pain is a result of the force exerted on the vaginal part of the cervix, the vagina and the perineum (Hulsbosch, et al., 2020).

Pain management is a universal aspect and one of the most important features and procedures of obstetric care and a major goal of intrapartum care. Pain relief plays an important role in overall maternal satisfaction with their labor experience and may promote their health and maternal wellbeing and their future motherchild relationship. A satisfactory labor experience may raise women's self-esteem and positive expectation for future labor (Rozek, et al., 2020).

The methods of pain relief can be basically dived into two broad categories: nonpharmacological pharmacological. Nonpharmacological are methods that help to decrease pain without taking medicines, easily applicable, do not cause side effects or allergy, affect labor progress positively, cheap and safe. Non-pharmacological methods are emotional support, massage, aroma therapy, hydrotherapy, intradermal water injection, TENS (Transcutaneous Electrical Nerve Stimulation), acupuncture, acupressure and hypnosis have been promulgated as non-pharmacological methods to relieve pain associated with childbirth (Czech, et al., 2018).

Pharmacological measures of labor pain relief include two types of drugs for pain relief; analgesics and anesthetics. Analgesics reduce and lessen pain without loss of consciousness, feeling or muscle function. On the other hand, anesthetics relieve pain by blocking most connected with the tension feeling, including pain. Pain relief medications can be systemic, regional and local. Systemic medications affect the entire body. Regional medications affect only a region of the body. Local medications are numbing medications usually affect a small area of the body and are extremely safe but, don't relieve the pain of labor contractions (American College of Obstetricians and Gynecologists, 2019).

Nurses have an important role in management of labor, when the nurse must use terms and language that the woman and family will understand and avoid medical terms. The nurse should witness that informed consent was obtained for performing any procedure as administration of regional anesthesia and clarify information with the woman and partner. Moreover, patient orientation to the department as physician room, nurses' room, bathrooms, room number and bed number, patient involvement by giving the opportunity to the woman and family to ask questions about care, maintaining confidentiality and keeping privacy (Tharpe, et al., 2021).

\section{Significance of the study}

Labor pain management is now accepted and implemented in many countries of the world. However, in Egypt, pain management during labor is not yet commonly practiced (Mousa, et al, 2018). Women may change their preferred delivery method due to fear of labor pain. So, this considers one of the most important reasons of increasing elective C.S rate in recent years. Studies showed that women with fear of labor require more use of pain-relieving methods in labor compered to women without fear of labor (Konlan et al, 2019). 
The pregnant women in developing countries are often unaware with methods of painless labor or pain relief during labor because it's not available, and this is lead to low demand for these services of labor pain relief. Ideally these methods should be no associated with side effects or risks to both mother and baby, make the woman comfortable, keep her free from pain and stress and at the same time keep the baby from the difficulties caused by the stress of the mother (Sharma, et al, 2018). Moreover, a lack of knowledge regarding the birth process can influence a women attitude to pain relief. Some women may understand the pain leading to birth and view her pain as positive and good signs of progress of labor. So, this study assessed the knowledge, attitude of pregnant women regarding painless labor (Çalik, et al, 2018).

\section{Aim of the study}

This study aimed to assess knowledge and attitudes of pregnant women regarding painless labor.

\section{Research questions:}

Q1: What is the level of knowledge .of women regarding painless labor?

Q2: What is the women's attitude regarding painless labor (positive or negative)?

\section{Subject and Methods}

Study design:

A descriptive study design was used to fulfill this study.

\section{Study setting:}

This study was conducted at Obstetrics \&gynecology department at Benha University Hospital (Outpatient Clinic). This hospital located in Benha City at Qalioubia Governorate.

\section{Sampling}

Sample type: A purposive sample was selected from the above-mentioned study setting.

Sample size: $10 \%$ of flow rate of all pregnant women (1500) (Benha University Hospital Statistical Census Center (2019) who attended at outpatient clinic (Obstetrics \& gynecology department) at Benha University Hospital. So, the sample was (150) woman.

The studied sample was selected according to the following criteria:

\section{Inclusion criteria:}

- Pregnant women with singleton pregnancy.

- Women in third trimester of pregnancy whatever their parity.

\section{Exclusion criteria include:}

- Pregnant women in the first or second trimester.

- Women who are scheduled for CS (permanent indication of CS).

\section{Sample technique:}

The investigator visited the study setting, introduced self to pregnant women and started the study according to the sequences women's number until finished all determined numbers.

\section{Tools of data collection:}

Two tools of data collection based on the review of literature. The required data for the present study were collected through development of two tools namely an interviewing-administered questionnaire sheet and Modified Likert's scale.

Tools I: An interviewing-administered questionnaire sheet: that includes two parts: It constructed by the investigator after reviewing a related literature and translated into Arabic language. It included: 
Part (1): Socio-demographic data (6 items): (Age, level of education, occupation, residence, and income)

Part (2): Maternal knowledge assessment questionnaire regarding painless labor which included the following:

(1) Knowledge related to painless labor: it consisted of (27) questions.

(2) Knowledge regarding vaginal delivery: it consisted of (5) questions.

\section{Scoring system of knowledge:}

All knowledge variables weighted according to items included in each question. These questions were multiple choice questions. Each question had three answers (correct, incorrect, and I don't know). The answers of the questions were classified into two categories. Score (1) for correct answer and score (0) for incorrect answer or (I don't know). Total knowledge score was converted into percentage and classified as the following:

- Good: ( $\geq 75 \%$ correct answer).

- Average: (50 - $75 \%$ correct answer).

- Poor: (<50\% correct answer).

\section{Tool II. Modified Likert's scale:}

It was adopted from (Alshahrani, 2019) and (Mousa, et al, 2018) and modified by the investigator and under supervision of supervisors to have a broader study about pregnant women's attitude. Likert's Scale would be used to assess pregnant women's attitude regarding painless labor. It allows the individuals to express how much the individuals agree or disagree with specific statement. The scale was consisted of (16) statements from three points Likert's scale type. It was translated into Arabic language and each item was evaluated and rated by three points Likert scale: agree, some times and disagree.

\section{Scoring system of attitude:}

To obtain the outcome of attitude scale, each statement scored as following; (2) if the response was "agree", (1) if it was 'some times', and (zero) if it was "disagree" The total score is expressed as a percentage. Total attitude score was converted into percentage and classified into:

Positive attitude: $50 \%<75 \%$

Negative attitude: $<50 \%$

\section{Validity of the tools:}

Tools of data collection were reviewed by three expertises in the field of Obstetrics and Gynecological Nursing at Faculty of Nursing, Benha University to test content validity and according to their judgment; the questionnaire was modified related to clarity of sentences and appropriateness of contents.

\section{Reliability of the tools:}

The reliability was done by Cronbach's Alpha coefficient test which revealed that; the internal consistency of knowledge was 0.86 ; the internal consistency of attitude was 0.80 .

\section{Ethical consideration:}

Ethical aspect was considered before starting the study that includes the following:

The research approval was obtained from Scientific Research Ethical Committee, Faculty of Nursing at Benha University before starting the study. An oral consent was obtained from each pregnant woman before starting data collection. The studied sample was informed about the purpose, benefits of the study and time throughout the study. The investigator emphasized that participation is voluntary. Each woman had the freedom to withdraw at any time of participation without obligation. The study didn't harm dignity, tradition and 


\section{Knowledge and Attitudes of Pregnant Women regarding Painless Labour}

religious aspects of the women. Confidentiality and privacy were ensured throughout the study process and the women were assured that all data was used only for research purpose.

\section{Pilot study}

A pilot study was carried out on $10 \%$ of total sample size which was (15) women before starting data collection to test the clarity, arrangement of the items, feasibility and applicability of the tools as well as to estimate the needed time to fill questions and to make sure that items are understood. No modifications were done and the pregnant women in the pilot study weren't excluded from the main study sample.

\section{Field work:}

The investigator had reviewed the national and international advanced literature, then design tool of data collection. The investigator had conducted pilot study to a certain content validity of tool used. The official approval to conduct the study was obtained by submission an official letter issued from the Dean of Faculty of Nursing at Benha University to the director of Benha University Hospital in order to obtain their agreement to conduct the study after explaining its purpose and get the statistical numbers of pregnant women follow up obstetric clinic enrolled within hospital annually. Upon obtaining official permission from director of Benha University Hospital, the study was carried out as the following:

The investigator began the study by visiting Benha University Hospital three days (Sundays, Mondays and Thursdays) from 9 to 12 a.m. The investigator introduced self and explained the aim and nature of the study then obtain oral consent from participants. After, that tool I, (An interviewing-administered questionnaire sheet) was given to pregnant women to fill the questionnaire and investigator filled the questionnaire for illiterate women.

Each interview took about 15-20 minutes. Then the studied women were interviewed to answer (Maternal knowledge assessment questionnaire). The time needed for this questionnaire ranged from 20 to 30 minutes. At the end, women were interviewed for tool II, (Modified Likert's scale) to assess their attitude regarding painless labor. The required time ranged from 10 to 15 minutes. These steps repeated until all predetermined sample size was completed.

\section{Statistical analysis:}

Data was verified prior to computerized entry. The statistical package for the social sciences (SPSS version 22) was used for that purpose followed by data tabulation and analysis. Descriptive statistics were applied (e.g., frequency and percent, mean, standard deviation SD, maximum and minimum). Test of significance (Chi-square X2) test was used in order to compare proportions between two qualitative parameters. Pearson correlation coefficient was used to test the association between the study variables.

No statistically significant difference obtained at $\mathrm{p}>0.05$.

Statistically significant difference obtained at $\mathrm{p}$ $<0.05$.

Highly statistically significant difference obtained at $\mathrm{p}<0.001$

\section{Result}

Table (1) shows the socio-demographic characteristics data of the studied sample, it was cleared that more than half $(56.0 \%)$ of the studied sample was in the age group of 25- 29 years with a mean age of $26.493 \pm 4.23$ years. Also, less than two-thirds $(60.7 \%)$ of them 
lived in rural areas. Regarding educational level, less than two-thirds of them (65.3\%) had secondary education. In relation occupation, more than half $(54.0 \%)$ of them were housewife. Moreover; the income of less than half of them $(48.0 \%)$ was not enough.

Figure (1) illustrates that, more than half of the studied women (54.7\%) had poor knowledge regarding painless labor, while more than one-quarter $(27.3 \%)$ of them had good knowledge.
Figure (2) illustrates that, more than half of the studied women $(57.3 \%)$ had negative attitude regarding painless labor, while more than two-fifth $(42.7 \%)$ of them had positive attitude.

Table (2) clarifies that, there was a highly statistically significant positive correlation between total knowledge and attitude scores regarding painless labor $(\mathrm{p} \leq 0.001)$.

Table (1): Frequency distribution of the studied sample regarding to their socio-demographic characteristics $(\mathbf{N}=150)$

\begin{tabular}{|c|c|c|}
\hline Socio-demographic characteristics & No & $\%$ \\
\hline \multicolumn{3}{|l|}{ Age in (vears) } \\
\hline $18-24$ & 38 & 25.3 \\
\hline $25-29$ & 84 & 56.0 \\
\hline$\geq 30$ & 28 & 18.7 \\
\hline \multicolumn{3}{|c|}{ Mean \pm SD $=26.493 \pm 4.23$} \\
\hline \multicolumn{3}{|l|}{ Residence: } \\
\hline Rural & 91 & 60.7 \\
\hline Urban & 59 & 39.3 \\
\hline \multicolumn{3}{|l|}{ Level of Education } \\
\hline Not read \& write & 2 & 1.3 \\
\hline Basic education & 21 & 14.0 \\
\hline Secondary education & 98 & 65.3 \\
\hline University education & 29 & 19.4 \\
\hline \multicolumn{3}{|l|}{ Occupation } \\
\hline Housewife & 81 & 54.0 \\
\hline Employed & 69 & 46.0 \\
\hline \multicolumn{3}{|l|}{ Income } \\
\hline Enough & 15 & 10.0 \\
\hline Fairly enough & 63 & 42.0 \\
\hline Not enough & 72 & 48.0 \\
\hline
\end{tabular}




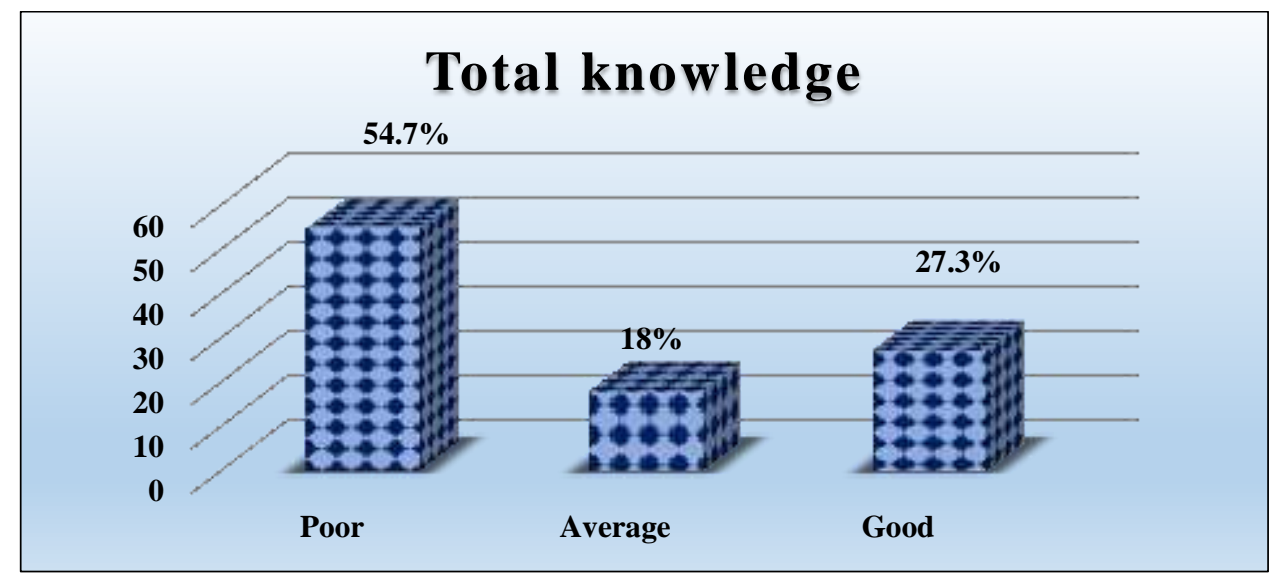

Figure (1): Percentage distribution of studied sample's total knowledge score regarding painless labor

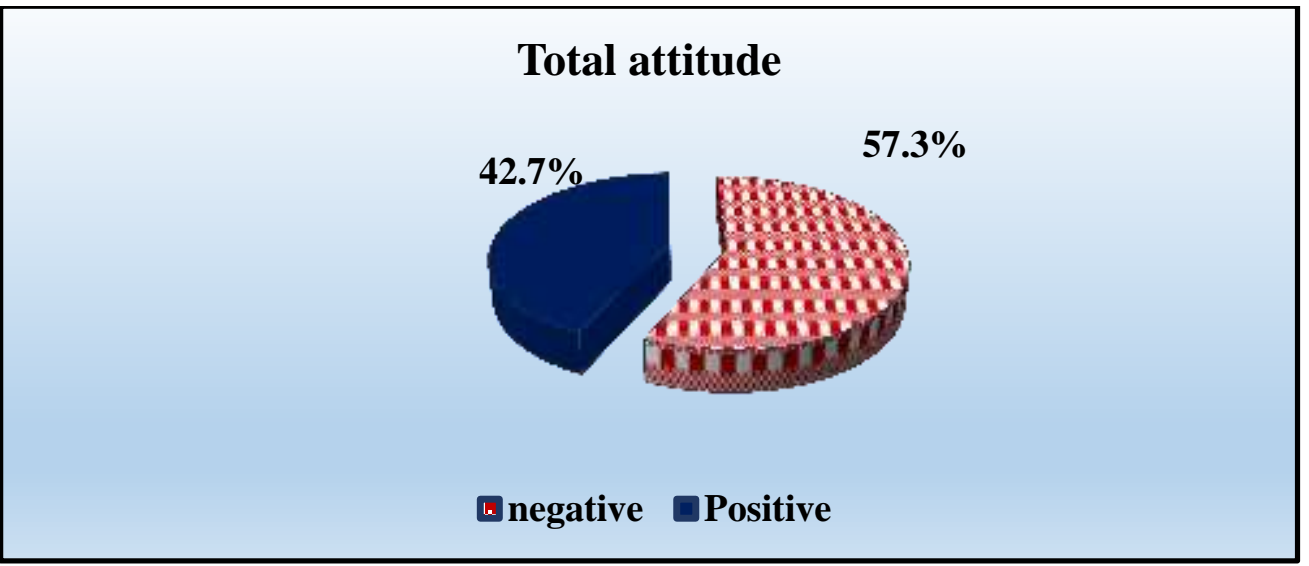

Figure (2): Percentage distribution of the studied sample regarding to their total attitude about painless labor

Table (2): Correlation coefficient between studied sample's total knowledge and attitude regarding painless labor $(\mathrm{N}=150)$.

\begin{tabular}{|l|c|c|}
\hline \multirow{2}{*}{ Variables } & \multicolumn{2}{|l|}{ Total knowledge } \\
\cline { 2 - 3 } & $\mathbf{r}$ & P value \\
\hline Total attitude & .445 & $\leq 0.001 *$ \\
\hline
\end{tabular}

$*$ A Statistically significant $\mathrm{p} \leq 0.05 * *$ A Highly Statistically significant $\mathrm{p} \leq 0.001$. 


\section{Asmaa Nabwy, Samia Abd-Elhakeem, Eman Mohamed and Ola Abdel-wahab}

\section{Discussion}

Among pregnant women, knowledge and attitudes concerning labor pain and painless labor are not known clearly especially in developing countries. The deficiency of knowledge and misunderstanding regarding safety, acceptability and availability of pain relief options are considered major factors of don't receiving adequate labor pain relief (Alsharidah and Alhuzaimi, 2018).

Therefore, this study aimed to assess knowledge and attitudes of pregnant women regarding painless labor.

It has been reported that women's socio-demographic characteristics play an essential role in shaping their knowledge and attitude (Jacob, 2019). Concerning the sociodemographic characteristics of studied sample, the current study findings showed that more than half of the studied sample were in the age group of 25- 29 years with mean age $26.493 \pm$ 4.23 years. Also, slightly more than three fifths of them lived in rural areas. Regarding educational level, less than two thirds of them had secondary education. In relation occupation, more than half of them were housewife. Moreover; the income of less than half of them was not enough.

Knowledge is a familiarity, awareness or understanding of someone or something as facts (descriptive knowledge) and skills (procedural knowledge) Lin and Spector, (2018). Health knowledge is considered to be one of the key factors that enable women to be aware of their rights, options and health status in order to seek appropriate health services. Studies have discovered that level of knowledge of mothers toward childbirth delivery is important for utilizing different labor service Ackley, et al, (2021).
Generally, it was showed that more than half of the studied sample had poor knowledge regarding painless labor, while more than one quarter of the them had good knowledge. This result went in the same harmony with Ezeonu, et al, (2017), in a study entitled "Perceptions and practice of epidural analgesia among women attending antenatal clinic in FETHA" found that more than three quarters of participants had incorrect answer regarding epidural analgesia. Moreover, Thomson, et al, (2019), in a study entitled "Women's experiences of pharmacological and non-pharmacological pain relief methods for labor and childbirth" reported that most women had correct knowledge about relaxation techniques. This result went in the same harmony with Karn, et al, (2016), who studied "Women's Awareness and Attitudes towards Labor Analgesia Influencing Practice between Developed and Developing Countries" found that large population of women has a lack of knowledge about the methods of painless childbirth. Also, Hasan, et al, (2016), who studied "Awareness and attitude of pregnant women towards labor analgesia in Babil province" found that most of the pregnant women showed poor general knowledge about painless labor. The results of this study were supported by Thakur, et al, (2017), in a study entitled "Knowledge and attitude regarding epidural analgesia among expectant mothers" who reported that less than half of expectant mothers had below average level of knowledge regarding labor analgesia. In the same context with this study, Shaaban, et al, (2018), found that majority of women had no Knowledge about labor analgesia. Sinha, et al, (2019), who found that more than 


\section{Knowledge and Attitudes of Pregnant Women regarding Painless Labour}

three quarters of women had no knowledge about painless delivery.

Moreover, this study was consistent with Delwatta, et al, (2019), who found that most of women had poor level of knowledge. Increasingly, Ali, et al, (2020), documented that the majority of women have insufficient knowledge regarding labor and labor analgesia. Additionally, Olaleye, et al, (2020) who carried out a study entitled "Awareness and Utilization of Obstetric Epidural Analgesia in Labor among Pregnant Women in Wesley Guild Hospital Ilesha, Nigeria" found that more than two fifths of the respondents had poor knowledge score about painless labor. Also, Alahmari, et al, (2020), in a study entitled "Knowledge, attitude, and practice of childbearing women toward epidural anesthesia during normal vaginal delivery in Alsanayeah Primary Health Care in Khamis Mushait" found that about two thirds of women had a low level of knowledge.

This result could be attributed to that large proportion of participants had their information from their friends and relative who are usually non-professionals. In addition, health care professionals do not provide adequate counseling about labor pain and about the options of labor analgesia during routine antenatal checkups. So, the invistigator believes that antenatal women should be educated about the need and benefit of pain relief and the available service. It may be done at an appropriate time by the obstetrician during the antenatal visits. The knowledge of pregnant women may also be improved by the provision of information leaflets, manuals, websites and childbirth preparation classes.

In the opposite direction of this study, Mattamundayil, et al, (2017), found that more than two thirds of women have an average knowledge on labor pain and its relief techniques. Also, this study was contradicted by Alsharidah and Alhuzaimi, (2018), who concluded that there was a good level of knowledge about the painless labor among studied sample. This difference in the knowledge level could be attributed to the education level and source of information of participants.

Attitude is a state of readiness or tendency to respond in a certain manner when confronted with certain stimuli. It is person's affective feelings of like and dislike which described as positive or negative. People attitudes are important determinants for their behavioral modification. Pregnant woman's personal attitude toward labor care services can either be positive or negative that may affect their decision for seeking care in their present pregnancy or refusing seeking care Drigo, et al, (2020).

In relation to total attitude, the current study findings clarified more than half of the studied sample had negative attitude regarding painless labor, while more than two fifth of the them had positive attitude.

In the same line with this study, Beigi, et al, (2010), in a study entitled "Women's experience of pain during childbirth" who documented that participant disagreed on the preference of CS. Also, Ezeonu, et al, (2017), in a study entitled "Perceptions and practice of epidural analgesia among women attending antenatal clinic in FETHA" found that less than three quarters of participants were uncertain about various forms of pain relief in labor. Moreover, Thomson, et al, (2019), in a study entitled "Women's experiences of pharmacological and non-pharmacological 
pain relief methods for labor and childbirth" reported that the common reason for painless labor was the use of epidural anesthesia.

The result of this study matched with Naithani, et al, (2011), in a study entitled "Knowledge, attitude and acceptance of antenatal women toward labor analgesia and caesarean section in a medical college hospital in India" found that attitude toward labor analgesia was relatively negative. Also, Ponnusamy, et al, (2012), in a study entitled "Awareness, knowledge and attitude about labor analgesia among providers and parturients" reported that pregnant women had negative attitude regarding labor analgesia. Additionally, Delwatta, et al, (2019), found that more than half of women had negative attitude level regarding labor epidural analgesia. This result was supported by Omotayo, et al, (2019), in a study entitled "Awareness, attitude and use of labor analgesics by pregnant women at State Specialist Hospital, Akure" who found that there was negative attitude toward labor analgesia use. Also, Alahmari, et al, (2020), showed that most females of childbearing age have a negative attitude level toward labor analgesia.

From investigator's point of view, this result could be explained by the fact that in developing countries, childbirth is viewed as a physiological process that does not require much interference. Also, lack of antenatal follow-up and explanations during the antenatal visits are responsible for the negative attitude toward painless labor.

In contrast to this study, Thakur, et al, (2017), reported an almost of participants had positive attitude regarding labor epidural analgesia. Mattamundayil, et al, (2017), found that majority of the participants had a favorable attitude toward painless labour techniques. Also, the result of our study was inconsistent with Alsharidah and Alhuzaimi, (2018), who concluded that there was positive attitude among women towards painless labor. Additionally, the result of current study was contradicted by Sinha, et al, (2019), who found that majority of women showed positive attitude towards painless labor. This discrepancy in the attitude level could be attributed to the knowledge level and previous experience of participants.

Concerning the correlation between studied sample's total knowledge and attitude regarding painless labor, the current study findings clarified that here was a highly statistically significant positive correlation between total knowledge and attitude scores regarding painless labor. This result was consistent with Thakur, et al, (2017), who reported that. There was moderate positive correlation between knowledge with attitude of expectant mothers toward labor epidural analgesia. Additionally, this result was in the same line with Sinha, et al, (2019), who found that there was statistically significant correlation between knowledge and attitude of pregnant women towards painless labor. Moreover, this result was in agreement with Delwatta, et al, (2019), who found that there were statistically significant associations between knowledge of women and their attitudes towards labor epidural analgesia.

From investigator's point of view, this result can be interpreted by great effect of knowledge on attitude the higher knowledge, the higher attitude. Finally, it was showed that the results of our study answered the study questions. 


\section{Conclusion}

More than half of the studied women had poor knowledge regarding painless labor. Regarding total attitude, more than half of the studied women had negative attitude regarding painless labor. So, there was a highly statistically significant positive correlation between total knowledge and attitude scores regarding painless labor. Finally, the findings of the current study were answered the study questions and achieved the aim of the study.

\section{Recommendations}

- Targeted public enlightenment and educational program should be done to mothers to improve the level of awareness regarding painless labor.

- Mother classes during antenatal visits must include colored posters, booklets and brochures to enhance women's perception regarding painless labor.

-Implementing and distributing nursing care guidelines regarding painless labor through antenatal clinic during initial visit of the pregnant women.

\section{Further studies:}

- Studying the women's satisfaction concerning application of methods of pain relief measures during labor.

- Comparative study that can be conducted to evaluate mothers' awareness regarding painless labor in urban and rural areas.

-Integrating painless labor in curriculum of nursing students.

- Comparative study that can be conducted to evaluate mothers' awareness regarding painless labor in urban and rural areas.

-Integrating painless labor in curriculum of nursing students.

-Designing and applying educational classes for the health care provider about painless labor at different antenatal clinics.

\section{References:}

Ackley, B., Ladwig, G., Makic, M., Martinez-Kratz, M., Zanotti, M. (2021). Nursing Diagnosis Handbook E-Book. An EvidenceBased Guide to Planning Care, 12th ed, Elshiever, Canada, P.224.

Alahmari, S., ALmetrek, M., Alzillaee, A., Hassan, W.and Shatha Alamry, M. (2020). Knowledge, attitude, and practice of childbearing women toward epidural anesthesia during normal vaginal delivery in Alsanayeah Primary Health Care in Khamis Mushait. Journal of Family Medicine and Primary Care; 9(1): 99-104.

Ali, M., Sultan, S., Kumar, A. and Ghouri, N. (2020). Knowledge, Attitude and Practices of Labor Analgesia amongst healthcare workers and patients A single center cross sectional study. Pakistani Journal of Medical Sciences;36(1): 4-8.

Alshahrani M.S. (2019). an evaluation of different types of labor pain relief, preferred methods of pain relief, and effects of social media on awareness and knowledge among pregnant women. Saudi Med; 40(9): 914-921

Alsharidah, D. and Alhuzaimi, F. (2018). Knowledge and attitude of Saudi women toward painless labor and misconception about risks and complications. International Journal of Advanced Research; 6(2): 1440-1449.

American College of Obstetricians and Gynecologists. (2019). ACOG practice bulletin no. 209: obstetric analgesia and anesthesia. Obstetrics and gynecology; 133(3): 208-225.

Beigi, N., Broumandfar, K., Bahadoran, P. and Abedi, H. (2010). Women's experience of pain during childbirth. Iran Journal of Nursing and Midwifery Research; 15(2): 77-82. 
Benha University Hospital statistical census center (2019). Annual obestatric department census

Czech, I., Fuchs, P., Fuchs, A., Lorek, M., Tobolska-Lorek, D., Drosdzol-Cop, A., \& Sikora, J. (2018). Pharmacological and nonpharmacological methods of labour pain relief-establishment of effectiveness and comparison. International journal of environmental research and public health, 15(12), 2792.

$\begin{array}{lcc}\text { Delwatta, S., } & \text { Kaushalya, } & \text { P., } \\ \text { Kankanamalage, } & \text { A., Shehan, }\end{array}$ Pilimatalawwe, C. and Prathapan, S. (2019). Is knowledge and attitude on epidural analgesia during labour satisfactory among pregnant women attending antenatal clinics in Colombo District. Sri Lankan Journal of Anesthesiology; 27(1): .21-27.

Drigo, L., Luvhengo, M., Lebese, R. and Makhado, L. (2020). Attitudes of Pregnant Women Towards Antenatal Care Services Provided in Primary Health Care Facilities of Mbombela Municipality, Mpumalanga Province, South Africa. The Open Public Health Journal; 13(20): 569-575.

Ezeonu, P., Anozie, O., Onu, F., Esike, C., Mamah, J., Lawani, L., Onoh, R., Ndukwe, E., Ewah, R. and Anozie, R. (2017). Perceptions and practice of epidural analgesia among women attending antenatal clinic in FETHA. International Journal of Women's Health; 17(9): 905-911

Farnham, T. (2020). Reviewing pain management options for patients in active labor. Nursing2021, 50(6), 24-30.

Hasan, M., Alsaadi, Z., Abbas, M. and Algoraby, J. (2016). Awareness and attitude of pregnant women towards labor analgesia in
Babil province. Medical Journal of Babylon; 13(1): 95-104.

Hulsbosch, L. P., Nyklíček, I., Potharst, E. S., Boekhorst, M. G., \& Pop, V. J. (2020). Development of the Labor Pain Relief Attitude Questionnaire for pregnant women (LPRAQp). BMC Pregnancy and Childbirth, 20(1), 112.

Jacob, A. (2019). A Comprehensive Textbook of Midwifery \& Gynecological Nursing. Jaypee Brothers Medical Publishers, India, P.140.

Karn, S., Yu, H., Karna, S., Chen, L., Qiao, D. (2016). Women's Awareness and Attitudes towards Labor Analgesia Influencing Practice between Developed and Developing Countries. Advances in Reproductive Sciences Journal; 4(2): 46-52.

Konlan K.D, Baku E.K, Japiong M, Konlan K.D and Amoah R.M. (2019). Reasons for Women's Choice of Elective Caesarian Section in Duayaw Nkwanta Hospital. Journal of Pregnancy; 1-7

Lin, L. and Spector, J. (2018). The Sciences of Learning and Instructional Design, Roultedge, imprint of Taylor \& Francis Publisher, United Kingdom, P.149.

Mattamundayil, A., Aranha, D. and Fernandes, P. (2017). A Study on the Knowledge, Attitude and Demand of Labour Pain Relief Techniques among Antenatal Women in a Selected Hospital at Mangaluru with a View to Prepare a Concept Map. International Journal of Health Sciences and Research; 7(11): 158-166.

Mousa O., Abdelhafez A.A, Abdelraheim A.R, Yousef A.M, Ghaney A.A and Elgelany S. (2018). Perceptions and Practice of Labor Pain-Relief Methods among Health Professionals Conducting Delivery in Minia 
Maternity Units in Egypt. Obstetrics and Gynecology International;1-6

Naithani, U., Bharwal, P., Chauhan, S., Kumar, D. and Gupta, S. (2011). Knowledge, attitude and acceptance of antenatal women toward labor analgesia and caesarean section in a medical college hospital in India. Journal of Obestatric Anethesia and Critical Care; 1(1): 13-20

Olaleye, O., Dada, S. and Alabi, G. (2020). Awareness and Utilization of Obstetric Epidural Analgesia in Labour among Pregnant Women in Wesley Guild Hospital Ilesha, Nigeria. International quarterly of community health education; 20(16): 1215-1222.

Omotayo, R., Akinsowon, O. and Omotayo, S. (2019). Awareness, attitude and use of labor analgesics by pregnant women at State Specialist Hospital, Akure. Tropical Journal of Obstetrics and Gynaecology; 36(2): 170-176.

Ponnusamy, R., Reddy, H. and Murugesan, R. (2012). Awareness, knowledge and attitude about labor analgesia among providers and parturients. Journal of Anaesthesia, Pain and Intensive Care; 22(1): 5-12.

Rozek, M., Smiech, Z., Kolacz, M., \& Kosson, D. (2020). Pain relief during laborwhat do we know and what should we know? Research based on the student population in warsaw. Wiadomości lekarskie, 73(7), 13391344.

Shaaban, O., Abbas, A., Mohamed, R. and Hafiz, H. (2018). Lack of pain relief during labor is blamable for the increase in the women demands towards cesarean delivery. Journal of Facts Views Vision in Obstetrics and gynecology; 9(4): 175-180.

Sinha, A., Abhilashi, K. and Prasad, D. (2019). Painless labour: attitude and awareness amongst pregnant women. International
Journal of Reproduction, Contraception Obstetrics and Gynecology; 8(3): 849-852

Thakur, M., Sagar, N., \& Tandon, P. (2017). Knowledge and attitude regarding epidural analgesia among expectant mothers. International Journal of Reproduction, Contraception, Obstetrics and Gynecology; 6(5): p, 1930.

Tharpe, N., Farley, C. and Jordan, R. (2021). Clinical Practice Guidelines for Midwifery \& Women's Health, 6th ed, Jones \& Bartlett Learning Publisher, USA, p:50-51.

Thomson G., Feeley C., Moran V.H., Downe S. and Oladapo O.T. (2019). Women's experiences of pharmacological and nonpharmacological pain relief methods for labour and childbirth. Reproductive health; 16(1):1-20 Sharma, M., Dhungel, S., Niroula, S., \& Karki, M. (2018). Knowledge and acceptance of labour analgesia in pregnant women. Journal of Nepal Health Research Council; 16(3): 302-306.

Çalik, K. Y., Karabulutlu, Ö., \& Yavuz, C. (2018). First do no harm-interventions during labor and maternal satisfaction: a descriptive cross-sectional study. BMC pregnancy and childbirth; 18(1): 1-10. 


\section{معلومات واتجاهات السيدات الحوامل فيما يتعلق بالوالدة بدون ألم}

أسماء نبوى حلمى - سامية عبد الحكيم حسانين عبود - ايمان حمد عبد الحكم - علا عبد الوهاب عفيفى

لا يعد التحكم والتعامل مع آلام الولادة مصدر قلق بالغ للأكهات في المستقبل فحسب، بل يمثل أيضًا

تحديًا كبيرًا في الطب الحديث. لذا هدفت الدر اسة الحالية إلى تقييم معلومات واتجاهات السيدات الحوامل فيما يتعلق بالو لادة بدون ألم ـ وقد أجريت هذه الدراسة في العيادات الخارجية لقسم النسا والتوليد بمستشفى بنها الجامعي على ، 10 سيده. حيث اتضح من النتائج أن أكثر من نصف السيدات الخاضعات للار اسة لديهن القليل من المعلومات عن الولادة بدون ألم. فيما يتعلق بالاتجاهات، كان لدى أكثر من نصف السيدات الخاضعات للار اسة اتجاه سلبي تجاه الو لادة بدون ألم. علاوة على ذلك، كانت هناك علاقة ذات دلالة إحصائية بين مجموع درجات المعلومات والاتجاهات فيما يتعلق بالو لادة بدون ألم و (العمر ، والإقامة، و المستوى التعليمي، والمهنة). بينما لا توجد علاقة ذات دلالة إحصائية بين مجموع درجات المعلومات الاتجاهات و الاخل. لذللك، كان هناك ارتباط إيجابي ذو دلالة إحصائية عالية بين مجموع المعلومات ودرجات الاتجاهات فيما يتعلق بالو لادة بدون ألم. و أخير اً قد أجابت نتائج الدراسة الحالية على أسئلة الدراسة وحققت الهدف منها. وأوصت الدراسة الي زيادة الوعي العام المستهدف والبر امج التعليمية للسيدات الحو امل لتحسين مستوى الوعي فيما يتعلق بالو لادة بدون ألم. 